\section{Fiscaoeconomia}

E-ISSN: 2564-7504

2022, Volume 6, Issue 1, 215-228

https://dergipark.org.tr/tr/pub/fsecon
Research Article/Araştırma Makalesi

Submitted/Geliş: 26.11.2021

Accepted/Kabul: 22.12 .2021

Doi: $10.25295 /$ fsecon. 1028730

\title{
Can Elon Mask's Twitter Posts About Cryptocurrencies Influence Cryptocurrency Markets by Creating a Herding Behavior Bias?
}

\section{Elon Musk'ın Kripto Paralar Hakkındaki Twitter Mesajları Bir Sürü Davranışı Eğilimi Yaratarak Kripto Para Piyasalarını Etkileyebilir mi?}

\section{Çağrı HAMURCU ${ }^{1}$}

\begin{abstract}
The main purpose of this study is to examine the effects of Elon Mask's Twitter posts about cryptocurrencies on cryptocurrency markets within the scope of herding behavior bias. For this purpose, the daily price values and transaction volumes of Bitcoin and Dogecoin are analyzed by applying the EGARCH models. The results show that Elon Musk's positive Twitter posts increase dogecoin's volatility more than bitcoin in terms of price and trading volume. In addition, the effect of positive tweets has been found to increase Bitcoin and Dogecoin prices and their market transactions. According to the results, while negative tweet sharing negatively affects bitcoin returns, it manifests itself with an increase in volatility after a certain period of time. Another result is that the Dogecoin return and negative tweet interaction vary according to time intervals, but the presence of the effect on volatility cannot be determined. It is also concluded that after the negative tweet, both bitcoin and dogecoin transaction volumes increased in the first days, but their volatility was not affected. The results are important in terms of showing the effects of an influential person's social media posts on the financial markets by creating a herd behavior effect. Revealing the "influential person effect" as a behavioral finance bias is seen as the originality of the study. It is thought that the findings can be evaluated in terms of pointing out a factor that may pose a potential risk to financial stability in the global sense.
\end{abstract}

Jel Codes: D9, E7, G4.

Keywords: Behavioral Finance, Social Media, Bitcoin, Dogecoin, Influential Person Effect, Twitter.

\footnotetext{
${ }^{1}$ Assist. Prof., Aksaray University, Ortakoy Vocational School of Higher Education, Department of Finance, Banking\&Insurance, Aksaray, Turkey, cagri.hamurcu@gmail.com, ORCID: 0000-0002-3248-6733
}

Citation/Atıf: Hamurcu, Ç. (2022). Can Elon Mask's Twitter Posts About Cryptocurrencies Influence Cryptocurrency Markets by Creating a Herding Behavior Bias? Fiscaoeconomia, 6(1), 215-228. Doi: 10.25295/fsecon.1028730. 
Hamurcu, Ç. (2022). Can Elon Mask's Twitter Posts About Cryptocurrencies Influence Cryptocurrency Markets by Creating a Herding Behavior Bias? Fiscaoeconomia, 6(1), 215-228.

Doi: 10.25295/fsecon.1028730.

Öz

Bu çalışmanın temel amacı, Elon Mask'in kripto paralar ile ilgili Twitter paylaşımlarının kripto para piyasaları üzerindeki etkilerini sürü davranışı eğilimi kapsamında incelemektir. Bu amaçla Bitcoin ve Dogecoin'in günlük fiyat değerleri ve işlem hacimleri EGARCH modelleri uygulanarak analiz edilmiştir. Sonuçlar, Elon Musk'ın olumlu içerikli Twitter gönderilerinin, fiyat ve işlem hacmi açısından dogecoin'in oynaklığını bitcoin'den daha fazla artırdığını göstermektedir. Ayrıca olumlu tweetlerinin etkisi, Bitcoin ve Dogecoin fiyatlarının ve bunlara ait piyasa işlemlerinin artmasına neden olduğu tespit edilmiştir. Sonuçlara göre olumsuz tweet paylaşımı bitcoin getirilerini olumsuz etkilerken belli bir süre sonra oynaklığın artmasıyla kendini göstermektedir. Diğer bir sonuç ise Dogecoin getirisi ve negatif tweet etkileşiminin zaman aralıklarına göre değişiklik göstermesi ancak volatilite üzerindeki etkisinin varlığının tespit edilememesidir. Ayrıca olumsuz tweetin ardından hem bitcoin hem de dogecoin işlem hacimlerinin ilk günlerde arttığı ancak oynaklıklarının etkilenmediği sonucuna varılmaktadır. Sonuçlar, etkili bir kişinin sosyal medya paylaşımlarının bir sürü davranışı etkisi oluşturarak bunun finansal piyasalar üzerindeki etkilerini göstermesi açısından önemlidir. "Etkili kişi etkisinin" davranışsal finans yanlılığı olarak ortaya çıkarılması çalışmanın özgünlüğü olarak görülmektedir. Bulguların küresel anlamda finansal istikrar için potansiyel risk oluşturabilecek bir faktöre işaret etmesi açısından değerlendirilebileceği düşünülmektedir.

Jel Kodları: D9, E7, G4.

Anahtar Kelimeler: Davranışsal Finans, Sosyal Medya, Bitcoin, Dogecoin, Etkili Kişi Etkisi, Twitter.

\section{Introduction}

Social media posts are important both for understanding human perceptions and for their potential to affect human perceptions. From this point of view, social media may have some effects on human behavior in decision-making processes and this situation may also manifest itself in financial decisions. The dynamic created by the mutual effects of social media and financial markets have become an important research subject.

A study was conducted by Shen, Urquhart, \& Wang (2019) examining the link between investor interest and Bitcoin returns, trading volume, and realized volatility. In this study, which was conducted with linear and nonlinear Granger causality tests, it was concluded that the number of Tweets was an important driver of the next day trading volume and actual volatility, supported by linear and nonlinear Granger causality tests. Recently, many studies have been carried out on Twitter and cryptocurrency markets. Kraaijeveld, \& De Smedt (2020) conclude in their paper that twitter sensitivity can predict the returns of Bitcoin, Bitcoin Cash, and Litecoin with lexicon-based sentiment analysis and EOS and TRON with a bullishness ratio approach. Zang (2020) revealed that while crypto coin values increased in response to Twitter sentiment, trading amounts increased in response to the absolute value. According to the results of Aharon, Demir, Lau, and Zaremba (2020), there is a clear causal correlation between ambiguity in social media posts and cryptocurrency returns of Bitcoin, Ethereum, Bitcoin Cash, and Ripple. In the study of Naeem, Mbarki, \& Shahzad (2021), it is discovered that although its predictability is low and valid for the short term, happiness sentiment is a permanent and 
Hamurcu, Ç. (2022). Can Elon Mask's Twitter Posts About Cryptocurrencies Influence Cryptocurrency Markets by Creating a Herding Behavior Bias? Fiscaoeconomia, 6(1), 215-228.

Doi: 10.25295/fsecon.1028730.

reliable indicator of certain cryptocurrency returns, whereas the fear index still indicates strong predictability of returns. Choi (2021), who examined the relationship between investor attention and bitcoin liquidity with the number of tweets, found that the positive effect of tweets decreased after about an hour and the effects on liquidity were stronger when tweets attracted more attention. In their article, Öztürk and Bilgin (2021) investigated whether tweets affect bitcoin returns or trading volume changes in terms of important Twitter accounts. The results of the study show that tweets can be used to predict bitcoin returns, and in particular, the most influential accounts, rather than all tweets, are the drivers of these returns. In his research, Ante (2021) shares the result that after every Twitter post by Elon Musk about cryptocurrencies, very crucial abnormal transaction volume and returns for Bitcoin and Dogecoin are detected (Ante, 2021).

Studies revealing that the decision-making process may result in some irrational behaviors under factors such as uncertainty (Tversky, and Kahneman, 1974) and risk (Kahneman, and Tversky, 1979) necessitate a multidimensional examination of irrationality. All these developments formed the basis of behavioral finance. Examining people's decision-making processes within the framework of various factors such as psychological, sociological, and cognitive contributes to understanding how the irrationality in human nature can affect individual investment decisions and the reflections of these effects in financial markets.

It is thought that people's sensitivity to social media also increases with the increase in use, and from this point of view, social media shares may create irrational effects on investors' decisions. In general, it can be thought that there are effects of herding behavior in this process. The herding behavior, which can occur during periods when the market has both a downward and an upward trend, is defined as a behavioral finance trend that can be limited to a short period of time, which manifests itself in the way investors follow the actions of others rather than their own information in order to gain more (Tan et al., 2008).

The effect of social media posts of influential people with characteristics such as global recognition, reputation, and wealth on financial markets has been wondered. For this purpose, the effects of Elon Mask's Twitter posts about cryptocurrencies on the cryptocurrency markets are investigated.

Elon Musk, CEO of Tesla, SpaceX, who is among the richest people in the world with a fortune of 151Billion, Elon Musk, CEO of Tesla, SpaceX, has 56.7 million Twitter followers (Musk, 2021). Tesla was charged to pay in Penalties by the Securities and Exchange Commission (SEC) for failing to have the necessary disclosure controls and procedures in place concerning Musk's tweet “Am considering taking Tesla private at $\$ 420$. Funding secured." on $7^{\text {th }}$ Aug 2018 (SEC, 2021). With Musk's tweet, the increase in Tesla's stock prices by more than 6 percent and the significant deterioration of the market were the reasons for the SEC's penalty.

\section{Material and Methods}

One-year (09.05.2020-12.05.2021) data of Bitcoin and Dogecoin cryptocurrencies, whose daily price values and transaction volumes are tried to be analyzed have been examined in the first part of the analysis. In this section, Twitter shares of Elon Musk, which are in Table 1, about cryptocurrencies are included in the analysis. 
Hamurcu, Ç. (2022). Can Elon Mask's Twitter Posts About Cryptocurrencies Influence Cryptocurrency Markets by Creating a Herding Behavior Bias? Fiscaoeconomia, 6(1), 215-228.

Doi: 10.25295/fsecon.1028730.

Firstly, an ANOVA test was applied to see whether there was a difference in the mean values of the series due to Twitter posts. Secondly, unit root tests are performed for the series of variables. Thirdly, the volatility of the series is evaluated with EGARCH (exponential generalized autoregressive conditional heteroskedasticity) models defined by Nelson (1991). Twitter dummy variable, which is determined as " 1 " for the days of Twitter posts, " 0 " for the other days, has been added to the models established. In the second part of the analysis, the effects of the negative tweet on the date of May the $13^{\text {th }}$ are evaluated ("Tesla has suspended vehicle purchases using bitcoin...").In this part of the analysis, the Twitter dummy variable, which was determined as " 1 " for the day and after the negative Twitter posting and " 0 " for the previous days, is added to the established models. These calculations are made separately for $5,10,15$, and 20-day time intervals.

Table 1: Elon Musk Tweets About Cryptocurrencies

\begin{tabular}{|c|c|}
\hline Date & Tweet \\
\hline 18.07.20 & It's inevitable. Excuse me, I only sell Doge. \\
\hline 20.12.20 & Bitcoin is my safe Word. \\
\hline 25.12 .20 & Merry Christmas \& happy holidays! A picture of Dogecoin is shared. \\
\hline 29.01 .21 & Posted a picture about Dogecoin, specifically the cover of a magazine named Dogue \\
\hline 04.02 .21 & I am become meme, Destroyer of shorts \\
\hline 06.02 .21 & The future currency of Earth (Dogecoin to the Moooonn, All other crypto combined) \\
\hline 07.02 .21 & "So ... it's finally come to this ..." Picture about Dogecoin is shared. \\
\hline 08.02 .21 & $\bigoplus$ is for Đogecoin! Instructional video. \\
\hline 10.02 .21 & Bought some Dogecoin for lil X, so he can be a toddler hodler \\
\hline 11.02 .21 & Frodo was the underdoge, All thought he would fail, Himself most of all. \\
\hline 15.02 .21 & I will literally pay actual \$ if they just void their accounts \\
\hline 19.02 .21 & $\begin{array}{l}\text { To be clear, I am *not* an investor, I am an engineer. I don't even own any publicly } \\
\text { traded stock besides Tesla. However, when fiat currency has negative real interest, } \\
\text { only a fool wouldn't look elsewhere. Bitcoin is almost as bs as fiat money. The key } \\
\text { word is "almost". }\end{array}$ \\
\hline 20.02 .21 & Heard a rumor some crypto coin was pegging the dollar \\
\hline 21.02 .21 & Cryptocurrency explained \\
\hline 22.02.21 & Dojo 4 Doge \\
\hline 24.02 .21 & Literally \\
\hline 01.03 .21 & Doge meme shield (legendary item) \\
\hline 02.03 .21 & Scammers \& crypto should get a room \\
\hline 12.03 .21 & Both do mining \& use blocks \& chains \\
\hline 14.03 .21 & Why are you so dogematic, they ask \\
\hline 15.03 .21 & I'm selling this song about NFTs as an NFT \\
\hline 24.03 .21 & You can now buy a Tesla with Bitcoin \\
\hline
\end{tabular}


Hamurcu, Ç. (2022). Can Elon Mask's Twitter Posts About Cryptocurrencies Influence Cryptocurrency Markets by Creating a Herding Behavior Bias? Fiscaoeconomia, 6(1), 215-228.

Doi: $10.25295 /$ fsecon.1028730.

\begin{tabular}{|ll|}
\hline 10.04.21 & ... going to moon very soon \\
\hline 15.04.21 & Doge Barking at the Moon \\
\hline 24.04 .21 & What does the future hodl? \\
\hline 07.05 .21 & Cryptocurrency is promising, but please invest with caution!" \\
\hline 08.05 .21 & Guest starring ... Picture about Dogecoin is shared. \\
\hline 10.05 .21 & $\begin{array}{l}\text { SpaceX launching satellite Doge-1 to the moon next year - Mission paid for in Doge - } \\
\text { 1st crypto in space - 1st meme in space To the mooooonnn!! }\end{array}$ \\
\hline
\end{tabular}

\section{Results}

The results of the analysis made in order to compare the variables of bitcoin and dogecoin price and transaction volume on the days of positive tweet sharing with other days are given in Table 2. It is seen that there are statistically significant differences $(p=0.0000<0.0100)$ between tweet sharing days and others. For both bitcoin and dogecoin, the mean values of price and transaction volumes in tweet sharing days are found higher than other days.

Performed unit root tests are revealed that the stationarity is determined in the first differences of the series. For this reason, the logarithmic differences of the variables are taken and used for the subsequent analysis. EGARCH models for both Bitcoin and Dogecoin are established in order to evaluate the relationship between variables in terms of volatility.

Table 2: The Effect of the Positive Tweets on Bitcoin and Dogecoin

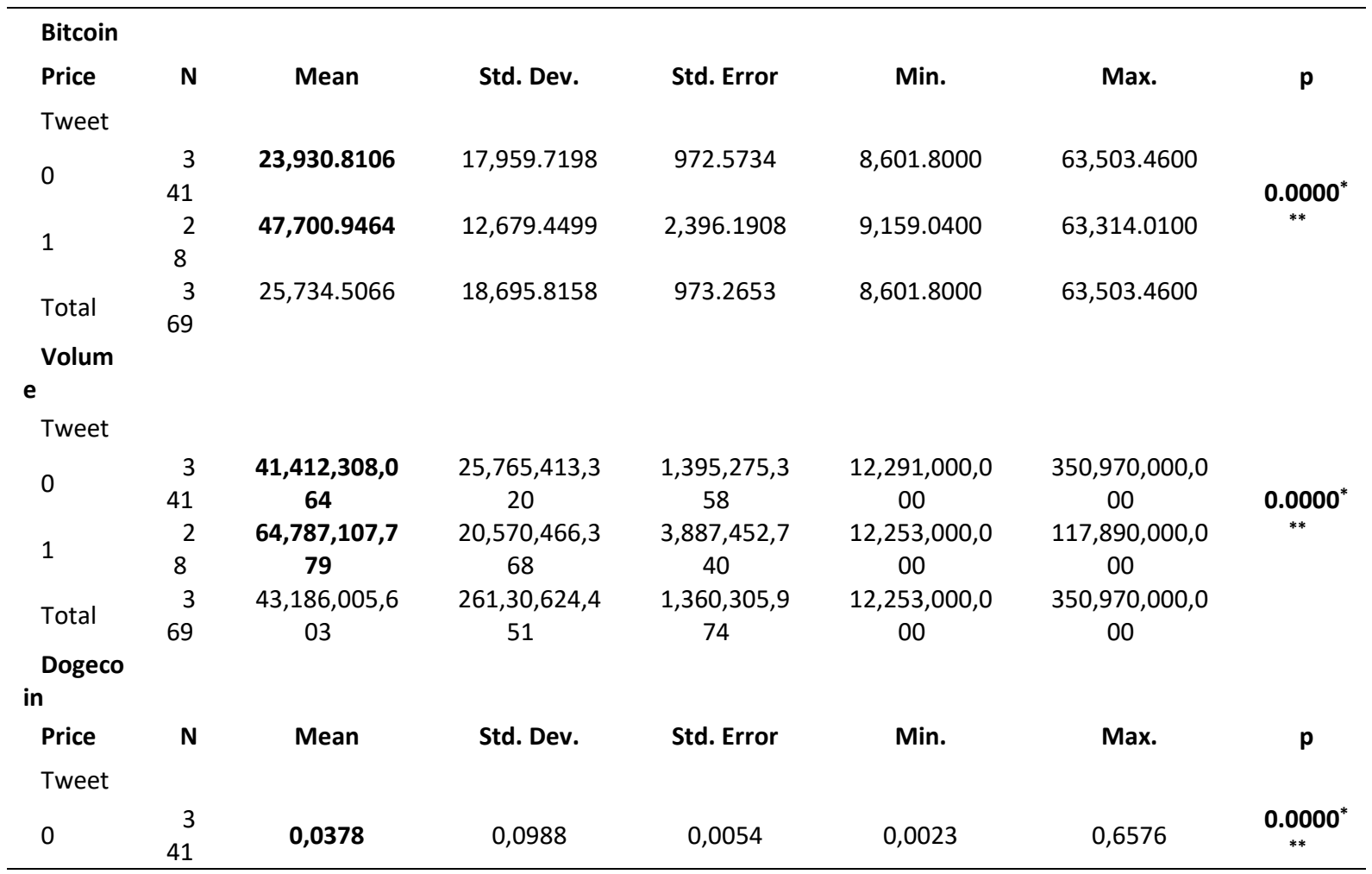


Hamurcu, Ç. (2022). Can Elon Mask's Twitter Posts About Cryptocurrencies Influence Cryptocurrency Markets by Creating a Herding Behavior Bias? Fiscaoeconomia, 6(1), 215-228.

Doi: $10.25295 /$ fsecon.1028730.

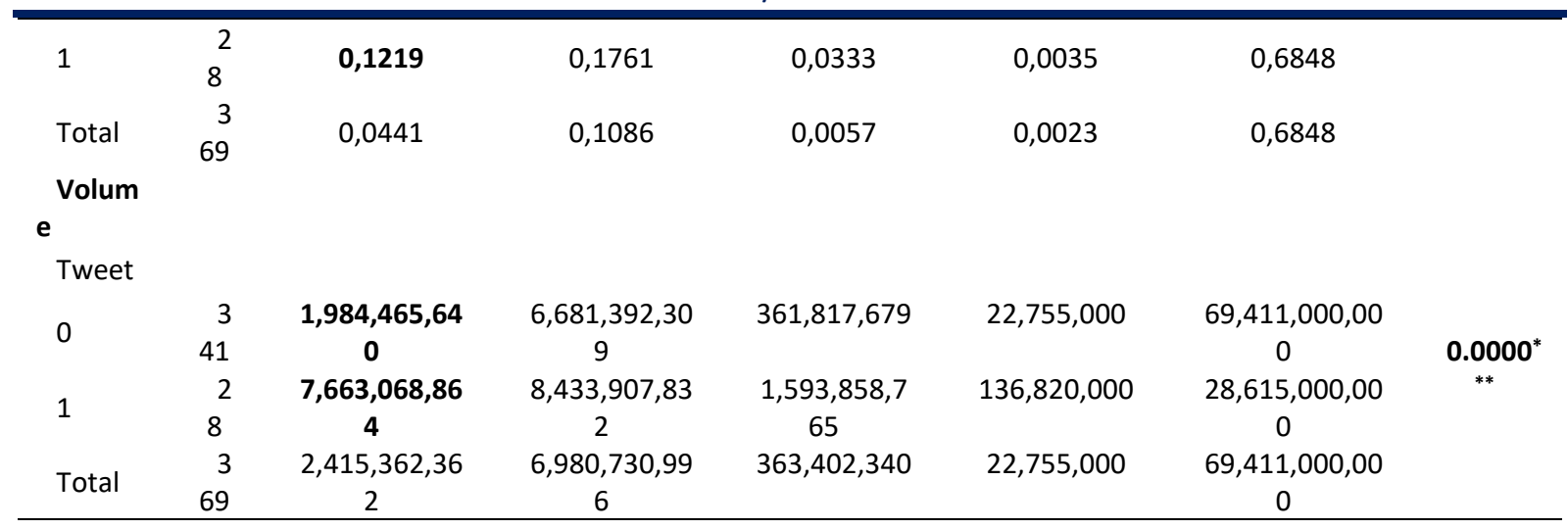

note: ${ }^{* * *}$ Significant at the $\% 1$ level.

The variance equation for EGARCH models is given in equation (1).

$\log \left(\sigma_{t}^{2}\right)=\alpha_{0}+\alpha_{1}\left|\varepsilon_{t-1} / \sigma_{t-1}\right|+\beta_{1}\left(\xi_{t-1} / \sigma_{t-1}\right)+\gamma_{1} \log \left(\sigma_{t-1}^{2}\right)+\mathrm{T}_{1}$ Tweet

In this equation:

$\xi_{t}$ is the prediction error

$\sigma_{t}^{2}$ is the conditional variance of $\xi_{t}$ given information at time $t$

$\alpha_{1}$ is an indicator of volatility size effect

$\beta_{1}$ is an indicator of the asymmetry volatility structure

$\gamma_{1}$ is an indicator of volatility persistence

$\mathrm{T} 1$ is an indicator of the Twitter dummy variable effect on volatility

The findings of the EGARCH models are given in Table 3. According to Table 3, when the price variables are examined, $\alpha 1$ coefficient of Dogecoin $(\alpha 1=1.7353)$ is much bigger than Bitcoin $(\alpha 1=0.1257)$ prices. By comparing the values based on asymmetry of variance, it can be shown that although Bitcoin price has a positive coefficient $(\beta 1=0.0513)$, Dogecoin has a negative coefficient $(\beta 1=-0.3398)$. As the models are compared in terms of volatility persistence, it is clear that bitcoin price $(\gamma 1=0.9451)$ has a higher coefficient than dogecoin $(\gamma 1=0.5240)$. Another finding obtained from the table is that dogecoin price $(T 1=0.5201)$ has a higher coefficient than bitcoin ( $\mathrm{T} 1=0.1682)$. 
Hamurcu, Ç. (2022). Can Elon Mask's Twitter Posts About Cryptocurrencies Influence Cryptocurrency Markets by Creating a Herding Behavior Bias? Fiscaoeconomia, 6(1), 215-228.

Doi: 10.25295/fsecon.1028730.

Table 3: EGARCH Models for Bitcoin and Dogecoin

\begin{tabular}{|c|c|c|c|c|c|c|c|c|}
\hline \multirow[t]{2}{*}{ Bitcoin } & \multicolumn{4}{|c|}{ Price } & \multicolumn{4}{|c|}{ Volume } \\
\hline & Coef. & S.E. & z-Statistic & $p$ & Coef. & S.E. & z-Statistic & $p$ \\
\hline \multicolumn{9}{|l|}{ M.E. } \\
\hline C & 0.0041 & 0.0017 & 2.3382 & $\underset{*}{0.0194^{*}}$ & 0.0225 & 0.0129 & 1.7421 & $0.0815^{*}$ \\
\hline \multicolumn{9}{|l|}{ V.E. } \\
\hline$\alpha_{0}$ & -0.4762 & 0.1478 & -3.2218 & $\underset{* *}{0.0013^{*}}$ & -0.4987 & 0.2147 & -2.3226 & $0.0202^{* *}$ \\
\hline$\alpha_{1}$ & 0.1257 & 0.0521 & 2.4129 & $\underset{*}{0.0158^{*}}$ & 0.1119 & 0.0668 & 1.6741 & $0.0941^{*}$ \\
\hline$\beta_{1}$ & 0.0513 & 0.0269 & 1.9085 & $0.0563^{*}$ & 0.2261 & 0.0572 & 3.9503 & $\underset{*}{0.0001^{* *}}$ \\
\hline$\gamma_{1}$ & 0.9451 & 0.0169 & 5.5880 & $\underset{* *}{0.0000^{*}}$ & 0.8664 & 0.0622 & 1.3939 & $\underset{*}{0.0000^{* *}}$ \\
\hline $\mathrm{T}_{1}$ & 0.1682 & 0.0525 & 3.2048 & $\underset{* *}{0.0014^{*}}$ & 0.4158 & 0.1879 & 2.2135 & $0.0269^{* *}$ \\
\hline \multirow{2}{*}{$n^{\text {Dogecoi }}$} & \multicolumn{4}{|c|}{ Price } & \multicolumn{4}{|c|}{ Volume } \\
\hline & Coef. & S.E. & z-Statistic & $p$ & Coef. & S.E. & z-Statistic & $p$ \\
\hline \multicolumn{9}{|l|}{ M.E. } \\
\hline C & 0.0008 & 0.0010 & 0.7638 & 0.4450 & 0.0028 & 0.0255 & 0.111239 & 0.9114 \\
\hline \multicolumn{9}{|l|}{$\underline{\text { V.E. }}$} \\
\hline$\alpha_{0}$ & -3.6135 & 0.2066 & -17.4900 & $\underset{* *}{0.0000^{*}}$ & -1.1717 & 0.1331 & -8.8048 & $\underset{*}{0.0000^{* *}}$ \\
\hline$\alpha_{1}$ & 1.7353 & 0.0541 & 32.0825 & $\underset{* *}{0.0000^{*}}$ & 0.5296 & 0.0878 & 6.0358 & $\underset{*}{0.0000^{* *}}$ \\
\hline$\beta_{1}$ & -0.3398 & 0.0663 & -5.1261 & $\underset{* *}{0.0000^{*}}$ & 0.3571 & 0.0650 & 5.4969 & $\underset{*}{0.0000^{* *}}$ \\
\hline$\gamma_{1}$ & 0.5240 & 0.0335 & 15.6383 & $\underset{* *}{0.0000^{*}}$ & 0.4931 & 0.0691 & 7.1351 & $\underset{*}{0.0000^{* *}}$ \\
\hline $\mathrm{T}_{1}$ & 0.5201 & 0.1926 & 2.7004 & $\underset{*}{0.0069^{*}}$ & 0.5588 & 0.1933 & 2.8908 & $0.0038^{* *}$ \\
\hline
\end{tabular}

note: $\mathrm{M} . \mathrm{E} .=$ mean equation. $\mathrm{V} . \mathrm{E} .=$ variance equation. $\mathrm{S} . \mathrm{E} .=$ Std. Error. $\mathrm{P}=$ probability.

${ }^{* * *}$ Significant at the $\% 1$ level. ${ }^{* *}$ Significant at the $\% 5$ level. ${ }^{*}$ Significant at the $\% 10$ level

The results of the EGARCH models in which the dummy Twitter variable belonging to the negative share is added to both the mean and variance equations are shown in Table 4 and Table 5 for bitcoin and dogecoin respectively. Analysis data of bitcoin and dogecoin transaction volumes are also available in Table 4.

Table 4 shows that the coefficient of $\alpha 1$ of bitcoin volume $(\alpha 1=0.1119)$ is smaller than that of Dogecoin $(\alpha 1=0.5296)$. There is a slight difference between the asymmetries in volatility and these values are $\beta 1=0.2261$ for bitcoin volume and $\beta 1=0.3571$ for dogecoin volume. When the volatility persistence is weighed, the volume of bitcoin $(\gamma 1=0.8664)$ outperforms dogecoin $(\gamma 1=0.4931)$. For the volume of bitcoin $(\mathrm{T} 1=0.4158)$, the impact of Twitter shares on volatility is lower than for Dogecoin volume $(\mathrm{T} 1=0.5588)$. When Table 4 is examined, it is seen that negative twitter sharing has a negative effect on bitcoin returns in all examined time intervals. 
Hamurcu, Ç. (2022). Can Elon Mask's Twitter Posts About Cryptocurrencies Influence Cryptocurrency Markets by Creating a Herding Behavior Bias? Fiscaoeconomia, 6(1), 215-228.

Doi: $10.25295 /$ fsecon.1028730.

Another finding obtained from the table is that this effect manifests itself as volatility increases starting from 15 days. No significant effects on volatility are seen for the 5 and 10day periods.

Table 4: The Effect of Negative Twitter Shares on Bitcoin Prices

\begin{tabular}{|c|c|c|c|c|c|c|c|c|}
\hline \multirow[t]{2}{*}{ Bitcoin } & \multicolumn{4}{|c|}{5 days } & \multicolumn{4}{|c|}{10 days } \\
\hline & Coef. & S.E. & z-Statistic & $p$ & Coef. & S.E. & z-Statistic & $p$ \\
\hline \multicolumn{9}{|l|}{ M.E. } \\
\hline C & 0.0126 & $2.47 \mathrm{E}-13$ & $5.08 \mathrm{E}+10$ & $\begin{array}{c}0.00 \\
00^{* * *}\end{array}$ & -0.0197 & $\begin{array}{l}5.8 \mathrm{E}- \\
106\end{array}$ & $-3.4 \mathrm{E}+103$ & $\begin{array}{c}0.0000^{* *} \\
*\end{array}$ \\
\hline $\mathrm{T} 1$ & $\begin{array}{c}- \\
0.0191\end{array}$ & $2.74 \mathrm{E}-06$ & -6955.8760 & $\begin{array}{c}0.00 \\
00^{* * *}\end{array}$ & -0.0452 & $\begin{array}{l}5.56 \mathrm{E}- \\
05\end{array}$ & -813.5011 & $\underset{*}{0.0000^{* *}}$ \\
\hline \multicolumn{9}{|l|}{ V.E. } \\
\hline$\alpha_{0}$ & $\begin{array}{c}- \\
5.2496\end{array}$ & 3.3285 & -1.5771 & $\begin{array}{l}0.11 \\
48\end{array}$ & -3.6755 & $\begin{array}{l}8.8 \mathrm{E}- \\
104\end{array}$ & $-4.2 E+103$ & $\begin{array}{c}0.0000^{* *} \\
*\end{array}$ \\
\hline$\alpha_{1}$ & $\begin{array}{c}- \\
2.6217\end{array}$ & 2.8556 & -0.9181 & $\begin{array}{l}0.35 \\
86\end{array}$ & -3.1226 & $\begin{array}{l}4.7 \mathrm{E}- \\
103\end{array}$ & $-6.7 E+102$ & $\begin{array}{c}0.0000^{* *} \\
*\end{array}$ \\
\hline$\beta_{1}$ & 4.7855 & 3.5482 & 1.3487 & $\begin{array}{l}0.17 \\
74\end{array}$ & -2.0338 & 0.4452 & -4.5687 & $\underset{*}{0.0000^{* *}}$ \\
\hline$\gamma_{1}$ & $\begin{array}{c}- \\
0.0742\end{array}$ & 0.4768 & -0.1557 & $\begin{array}{l}0.87 \\
63\end{array}$ & -0.0095 & 0.0069 & -1.3793 & 0.1678 \\
\hline \multirow[t]{3}{*}{$\mathrm{T}_{1}$} & $\begin{array}{c}- \\
2.8972\end{array}$ & 2.0888 & -1.3870 & $\begin{array}{l}0.16 \\
54\end{array}$ & 0.7474 & 0.4912 & 1.5218 & 0.1281 \\
\hline & \multicolumn{4}{|c|}{15 days } & \multicolumn{4}{|c|}{20 days } \\
\hline & Coef. & S.E. & z-Statistic & $p$ & Coef. & S.E. & z-Statistic & $p$ \\
\hline \multicolumn{9}{|l|}{ M.E. } \\
\hline C & $\begin{array}{c}- \\
0.0158\end{array}$ & 0.0042 & -3.7471 & $\begin{array}{c}0.00 \\
02^{* * *}\end{array}$ & -0.0044 & 0.0002 & -1.7865 & $\underset{*}{0.0000^{* *}}$ \\
\hline $\mathrm{T} 1$ & $\begin{array}{c}- \\
0.0061\end{array}$ & 0.0155 & -0.3965 & $\begin{array}{l}0.69 \\
18\end{array}$ & -0.0176 & 0.0002 & -8.2137 & $\underset{*}{0.0000^{* *}}$ \\
\hline \multicolumn{9}{|l|}{ V.E. } \\
\hline$\alpha_{0}$ & $\begin{array}{c}- \\
2.0612\end{array}$ & 0.0001 & -320.1062 & $\begin{array}{c}0.00 \\
00^{* * *}\end{array}$ & -2.8905 & 0.0134 & -216.1832 & $\begin{array}{c}0.0000^{* *} \\
*\end{array}$ \\
\hline$\alpha_{1}$ & 2.5410 & 0.0397 & -64.0525 & $\begin{array}{c}0.00 \\
00^{* * *}\end{array}$ & -3.2159 & 0.4670 & -6.8871 & $\begin{array}{c}0.0000^{* *} \\
*\end{array}$ \\
\hline$\beta_{1}$ & $\begin{array}{c}- \\
1.2834\end{array}$ & 0.6605 & -1.9432 & $\begin{array}{l}0.05 \\
20^{*}\end{array}$ & -2.2401 & 0.3639 & -6.1556 & $\underset{*}{0.0000^{* *}}$ \\
\hline$\gamma_{1}$ & 0.3887 & 0.0023 & 169.0888 & $\begin{array}{c}0.00 \\
00^{* * *}\end{array}$ & 0.2313 & 0.0397 & 5.8312 & $\underset{*}{0.0000^{* *}}$ \\
\hline $\mathrm{T}_{1}$ & 0.6105 & 0.3695 & 1.6520 & $\begin{array}{l}0.09 \\
85^{*}\end{array}$ & 0.8253 & 0.1008 & 8.1859 & $\underset{*}{0.0000^{* *}}$ \\
\hline
\end{tabular}

note: $\mathrm{M} . \mathrm{E} .=$ mean equation. $\mathrm{V} . \mathrm{E} .=$ variance equation. $\mathrm{S} . \mathrm{E} .=$ Std. Error. $\mathrm{P}=$ probability.

${ }^{* * *}$ Significant at the $\% 1$ level. ${ }^{* *}$ Significant at the $\% 5$ level. ${ }^{*}$ Significant at the $\% 10$ level

According to Table 5, on one hand, positive returns for dogecoin are determined for a 5-day time interval, on the other hand, negative returns for 15-day. Moreover, no tweet return relationships are found for the 10 and 20-day time intervals. It is understood from Table 5 that the negative share has no effect on dogecoin volatility for all time periods. 
Hamurcu, Ç. (2022). Can Elon Mask's Twitter Posts About Cryptocurrencies Influence Cryptocurrency Markets by Creating a Herding Behavior Bias? Fiscaoeconomia, 6(1), 215-228.

Doi: $10.25295 /$ fsecon.1028730.

\begin{tabular}{|c|c|c|c|c|c|c|c|c|}
\hline \multirow{3}{*}{ Bitcoin } & \multicolumn{7}{|c|}{ Table 5: The Effect of Negative Twitter Shares on Dogecoin Prices } & \multirow[b]{3}{*}{$\mathrm{p}$} \\
\hline & \multicolumn{4}{|c|}{5 days } & \multicolumn{3}{|c|}{10 days } & \\
\hline & Coef. & S.E. & z-Statistic & $\mathrm{p}$ & Coef. & S.E. & z-Statistic & \\
\hline \multicolumn{9}{|l|}{ M.E. } \\
\hline C & -0.1690 & 0.0372 & -4.5365 & $\underset{*}{0.0000^{* *}}$ & -0.0122 & 0.0346 & -0.3539 & 0.7234 \\
\hline $\mathrm{T} 1$ & 0.1291 & 0.0633 & 2.0388 & $0.0415^{* *}$ & 0.0182 & 0.0425 & 0.4279 & 0.6687 \\
\hline \multicolumn{9}{|l|}{$\underline{\text { V.E. }}$} \\
\hline$\alpha_{0}$ & -7.5128 & 1.8900 & -3.9750 & $\underset{*}{0.0001^{* *}}$ & 0.0958 & 0.3854 & 0.2485 & 0.8037 \\
\hline$\alpha_{1}$ & 7.1960 & 6.2982 & 1.1425 & 0.2532 & -2.1822 & 0.0023 & -9.6787 & $*$ \\
\hline$\beta_{1}$ & -1.8695 & 2.3811 & -0.7851 & 0.4324 & -0.0072 & 0.8911 & -0.0081 & $\begin{array}{c}0.9935 \\
0.0000^{* *}\end{array}$ \\
\hline$\gamma_{1}$ & 0.6397 & 0.8878 & 0.7206 & 0.4712 & 0.4502 & 0.0075 & 5.9808 & $*$ \\
\hline $\mathrm{T}_{1}$ & -3.8814 & 4.2124 & -0.9214 & 0.3568 & -0.4755 & 1.3673 & -0.3478 & 0.7280 \\
\hline \multirow{2}{*}{$\begin{array}{l}\text { Dogecoi } \\
n\end{array}$} & \multicolumn{4}{|c|}{15 days } & \multicolumn{4}{|c|}{20 days } \\
\hline & Coef. & S.E. & z-Statistic & $\mathrm{p}$ & Coef. & S.E. & z-Statistic & $\mathrm{p}$ \\
\hline \multicolumn{9}{|l|}{$\underline{\text { M.E. }}$} \\
\hline C & 0.0503 & 0.0456 & 1.1025 & 0.2702 & 0.0197 & 0.0428 & 0.4608 & 0.6449 \\
\hline T1 & -0.0903 & 0.0500 & -1.8070 & $0.0708^{*}$ & -0.0403 & 0.0505 & -0.7986 & 0.4245 \\
\hline \multicolumn{9}{|l|}{$\underline{\text { V.E. }}$} \\
\hline$\alpha_{0}$ & -0.0353 & 0.7016 & -0.0504 & 0.9598 & 0.2215 & 0.1242 & 1.7835 & 0.0745 \\
\hline$\alpha_{1}$ & -1.1420 & 0.5531 & -2.0648 & 0.0389 & -0.7284 & 0.1753 & -4.1549 & $\underset{*}{0.0000^{* *}}$ \\
\hline$\beta_{1}$ & -0.6012 & 0.4559 & -1.3186 & 0.1873 & -0.2025 & 0.4427 & -0.4574 & 0.6474 \\
\hline$\gamma_{1}$ & 0.7218 & 0.1538 & 4.6920 & $\underset{*}{0.0000^{* *}}$ & 0.8995 & 0.0000 & $7.4 \mathrm{E}+102$ & $\underset{*}{0.0000^{* *}}$ \\
\hline $\mathrm{T}_{1}$ & -0.3886 & 0.3434 & -1.1315 & 0.2578 & -0.1354 & 0.1606 & -0.8430 & 0.3992 \\
\hline
\end{tabular}

note: M.E. = mean equation. V.E. = variance equation. S.E.= Std. Error. $\mathrm{P}=$ probability.

${ }^{* * *}$ Significant at the $\% 1$ level. ${ }^{* *}$ Significant at the $\% 5$ level. ${ }^{*}$ Significant at the $\% 10$ level

When tables 6 and 7 are examined, it is understood that while the negative tweet created an increased effect in both bitcoin and dogecoin transaction volumes in the first days (5 days), this effect disappeared and had no effect on volatility. 
Hamurcu, Ç. (2022). Can Elon Mask's Twitter Posts About Cryptocurrencies Influence Cryptocurrency Markets by Creating a Herding Behavior Bias? Fiscaoeconomia, 6(1), 215-228.

Doi: 10.25295/fsecon.1028730.

\begin{tabular}{|c|c|c|c|c|c|c|c|c|}
\hline \multicolumn{9}{|c|}{ Table 6: The Effect of Negative Twitter Shares on Bitcoin Transaction Volume } \\
\hline & \multicolumn{4}{|c|}{5 days } & \multicolumn{4}{|c|}{10 days } \\
\hline & Coef. & S.E. & z-Statistic & $\mathrm{p}$ & Coef. & S.E. & z-Statistic & $\mathrm{p}$ \\
\hline \multicolumn{9}{|l|}{ M.E. } \\
\hline C & 0.0472 & 4.2E-105 & $1.1 \mathrm{E}+103$ & $0.0000^{* * *}$ & 0.0442 & 0.0158 & 2.7910 & 0.0053 \\
\hline T1 & 0.0124 & $5.76 \mathrm{E}-08$ & 214875.7 & $0.0000^{* * *}$ & 0.0231 & 0.0153 & 1.5162 & 0.1295 \\
\hline \multicolumn{9}{|l|}{ V.E. } \\
\hline$\alpha_{0}$ & -0.3527 & 7.5621 & -0.0466 & 0.9628 & -6.8940 & 0.0089 & -771.1041 & $0.0000^{* * *}$ \\
\hline$\alpha_{1}$ & -3.5063 & 7.6997 & -0.4554 & 0.6488 & 5.2420 & 2.1510 & 2.4370 & 0.0148 \\
\hline$\beta_{1}$ & 3.5903 & 3.8662 & 0.9286 & 0.3531 & 0.6381 & 1.1077 & 0.5761 & 0.5646 \\
\hline$\gamma_{1}$ & 0.2119 & 3.0898 & 0.0686 & 0.9453 & 0.1348 & 0.4723 & 0.2855 & 0.7752 \\
\hline $\mathrm{T}_{1}$ & -2.3120 & 8.6860 & -0.2662 & 0.7901 & -1.1814 & 2.4888 & -0.4747 & 0.6350 \\
\hline \multirow[t]{2}{*}{ Dogecoin } & \multicolumn{4}{|c|}{15 days } & \multicolumn{4}{|c|}{20 days } \\
\hline & Coef. & S.E. & z-Statistic & $\mathrm{p}$ & Coef. & S.E. & z-Statistic & $\mathrm{p}$ \\
\hline \multicolumn{9}{|l|}{ M.E. } \\
\hline C & 0.0025 & 0.0242 & 0.1035 & 0.9175 & -0.0112 & 0.0344 & -0.3253 & 0.7450 \\
\hline $\mathrm{T} 1$ & -0.0304 & 0.0586 & -0.5199 & 0.6031 & 0.0027 & 0.0573 & 0.0467 & 0.9628 \\
\hline \multicolumn{9}{|l|}{ V.E. } \\
\hline$\alpha_{0}$ & -3.8581 & 1.3794 & -2.7970 & 0.0052 & -2.5020 & 1.8428 & -1.3577 & 0.1746 \\
\hline$\alpha_{1}$ & 1.5424 & 0.8414 & 1.8332 & 0.0668 & 0.9873 & 0.6481 & 1.5234 & 0.1277 \\
\hline$\beta_{1}$ & -0.2296 & 0.5085 & -0.4515 & 0.6516 & 0.0030 & 0.3891 & 0.0077 & 0.9939 \\
\hline$\gamma_{1}$ & 0.3847 & 0.4232 & 0.9090 & 0.3634 & 0.4822 & 0.5652 & 0.8532 & 0.3936 \\
\hline $\mathrm{T}_{1}$ & 1.2668 & 0.9551 & 1.3263 & 0.1848 & 0.4733 & 0.6302 & 0.7511 & 0.4526 \\
\hline
\end{tabular}

note: $M . E .=$ mean equation. V.E. = variance equation. S.E. $=$ Std. Error. $\mathrm{P}=$ probability.

${ }^{* * *}$ Significant at the $\% 1$ level. ${ }^{* *}$ Significant at the $\% 5$ level. ${ }^{*}$ Significant at the $\% 10$ level 
Hamurcu, Ç. (2022). Can Elon Mask's Twitter Posts About Cryptocurrencies Influence Cryptocurrency Markets by Creating a Herding Behavior Bias? Fiscaoeconomia, 6(1), 215-228.

Doi: $10.25295 /$ fsecon.1028730.

\begin{tabular}{|c|c|c|c|c|c|c|c|c|}
\hline \multirow[t]{2}{*}{ Bitcoin } & \multicolumn{4}{|c|}{5 days } & \multicolumn{4}{|c|}{10 days } \\
\hline & Coef. & S.E. & z-Statistic & $\mathrm{p}$ & Coef. & S.E. & z-Statistic & $\mathrm{p}$ \\
\hline \multicolumn{9}{|l|}{ M.E. } \\
\hline C & -0.1255 & $2.75 \mathrm{E}-05$ & -4569.9940 & $0.0000^{* * *}$ & -0.0523 & 0.0427 & -1.2237 & 0.2211 \\
\hline $\mathrm{T} 1$ & 0.0950 & $1.59 \mathrm{E}-10$ & $5.97 E+08$ & $0.0000^{* * *}$ & -0.0928 & 0.0644 & -1.4395 & 0.1500 \\
\hline \multicolumn{9}{|l|}{ V.E. } \\
\hline$\alpha_{0}$ & -0.3039 & 0.5597 & -0.5429 & 0.5872 & 1.3102 & 0.0032 & 410.5367 & $0.0000^{* * *}$ \\
\hline$\alpha_{1}$ & -4.6640 & 1.0602 & -4.3991 & $0.0000^{* * *}$ & -2.7664 & 0.0019 & -1435.0930 & $0.0000^{* * *}$ \\
\hline$\beta_{1}$ & 2.4491 & 0.9380 & 2.6111 & 0.0090 & 0.0328 & 0.6722 & 0.0488 & 0.9611 \\
\hline$\gamma_{1}$ & -0.1311 & 0.1462 & -0.8965 & 0.3700 & 0.1636 & 0.2080 & 0.7866 & 0.4315 \\
\hline $\mathrm{T}_{1}$ & -0.2089 & 0.5264 & -0.3970 & 0.6914 & -0.5135 & 0.7687 & -0.6680 & 0.5041 \\
\hline \multirow[t]{2}{*}{ Dogecoin } & \multicolumn{4}{|c|}{15 days } & \multicolumn{4}{|c|}{20 days } \\
\hline & Coef. & S.E. & z-Statistic & $\mathrm{p}$ & Coef. & S.E. & z-Statistic & $p$ \\
\hline \multicolumn{9}{|l|}{ M.E. } \\
\hline C & -0.0245 & 0.1521 & -0.1610 & 0.8721 & -0.1048 & 0.0801 & -1.3087 & 0.1906 \\
\hline $\mathrm{T} 1$ & -0.2391 & 0.1749 & -1.3671 & 0.1716 & -0.0528 & 0.0749 & -0.7045 & 0.4811 \\
\hline V.E. & & & & & -0.1048 & 0.0801 & -1.3087 & 0.1906 \\
\hline$\alpha_{0}$ & 0.8233 & 0.0669 & 12.3031 & $0.0000^{* * *}$ & 0.7298 & $1.2 \mathrm{E}-103$ & $6.1 \mathrm{E}+102$ & $0.0000^{* * *}$ \\
\hline$\alpha_{1}$ & -1.1738 & 0.0012 & -1014.8860 & $0.0000^{* * *}$ & -1.3999 & $2.7 \mathrm{E}-103$ & $-5.2 E+102$ & $0.0000^{* * *}$ \\
\hline$\beta_{1}$ & -0.1825 & 0.2888 & -0.6318 & 0.5275 & -0.0755 & 0.2101 & -0.3596 & 0.7192 \\
\hline$\gamma_{1}$ & 0.7676 & $\begin{array}{c}0.2287 \\
0.51653\end{array}$ & 3.3570 & $0.0008^{* * *}$ & 0.6504 & $1.60 \mathrm{E}-05$ & 40624.0300 & $0.0000^{* * *}$ \\
\hline $\mathrm{T}_{1}$ & -0.386374 & 3 & -0.748013 & 0.4545 & -0.2692 & 0.1756 & -1.5329 & 0.1253 \\
\hline
\end{tabular}

note: $\mathrm{M} . \mathrm{E} .=$ mean equation. V.E. $=$ variance equation. $\mathrm{S} . \mathrm{E} .=$ Std. Error. $\mathrm{P}=$ probability.

${ }^{* * *}$ Significant at the $\% 1$ level. ${ }^{* *}$ Significant at the $\% 5$ level. ${ }^{*}$ Significant at the $\% 10$ level

\section{Discussion and Conclusion}

The first finding shows that positive Twitter shares with cryptocurrencies have positive effects on both bitcoin and dogecoin and their prices and market transactions are increasing.

It is revealed that the sensitivity (coefficient $\alpha 1$ ) of Dogecoin price to volatility is bigger than Bitcoin. It means that price fluctuations have a heavier impact on the stock market volatility of dogecoin than bitcoin. Returns shocks that are larger in magnitude, whether positive or negative, would have a greater impact on the price volatility than smaller shocks. When the values based on asymmetry of variance for variables (coefficient $\beta 1$ ) are considered, it is evaluated that there are asymmetries in the volatility structure in both Bitcoin and Dogecoin. Positive shocks of equal magnitude have a greater effect on conditional volatility than negative shocks for Bitcoin. The opposite of this dynamic has been found for Dogecoin. The volatility persistence (coefficient $\gamma 1$ ) of Bitcoin is longer than Dogecoin. This finding could be interpreted as volatility in the Bitcoin market taking longer compared to Dogecoin. There are 
Hamurcu, Ç. (2022). Can Elon Mask's Twitter Posts About Cryptocurrencies Influence Cryptocurrency Markets by Creating a Herding Behavior Bias? Fiscaoeconomia, 6(1), 215-228.

Doi: $10.25295 /$ fsecon.1028730.

leverage effects in both cryptocurrency markets. Tweets are increasing the volatility of Dogecoin more than Bitcoin (coefficient T1). This result is consistent with the volatility sensitivity finding among cryptocurrencies.

Although the volatility magnitude effect (coefficient $\alpha 1$ ) is smaller for Bitcoin transaction volume than Dogecoin. This means long memory volatility for Dogecoin. In the Dogecoin market, there is a high exposure to market fluctuations and a higher volatility response to market shocks. The shock effect of both bitcoin and dogecoin on transaction volumes (coefficient $\beta 1$ ) is found as asymmetrical. Positive shocks have a greater effect on transaction volumes than negatives for both markets. As the subject comes to trade volume volatility persistence (coefficient $\gamma 1$ ), Bitcoin outperforms Dogecoin. This means that the volatility in the Dogecoin market continues shorter than Bitcoin in terms of market transaction volume. The impact of Twitter shares on transaction volume volatility for Dogecoin is higher than Bitcoin (coefficient T1).

The effects of negative tweets about cryptocurrencies on returns and trading volume have been determined as follows. This negative sharing has a negative effect on bitcoin returns in all examined time intervals and creating volatility increasing for 15 and 20 days. No significant effects on volatility are seen for the 5 and 10-day periods. As a result of this effect, the increase in volatility occurs after 15 days. It is considered as a result that can be deduced from these results that the increasing effect of the decrease in the returns on the volatility begins after 15 days. While this effect is detected positively in the first days ( 5 days) in terms of return on dogecoin, it loses its effect (10 days later), then shows itself with a negative formation (15 days later), and then disappears. The effect of sharing with negative content on dogecoin volatility could not be determined.

The analysis results of the models examining the effects of negative tweets on the trading volumes of cryptocurrencies indicate that both bitcoin and dogecoin showed an effect with an increase in the first days, but did not have an effect on volatility.

The findings obtained in this study are compatible with the studies conducted by Öztürk and Bilgin (2021) and Ante (2021), in terms of revealing the effects of tweet sharing of important accounts on the returns and transaction volumes of cryptocurrencies. The findings are considered to be significant in terms of demonstrating the impact of influencer people's social media shares on financial markets. The originality is shown by revealing the "influential person effect" approach as a behavioral finance tendency. It is thought that the findings can be evaluated in terms of pointing out a factor that may pose a potential risk to financial stability in the global sense. It is among the limitations of the study that only two cryptocurrencies are included in the study and the date range examined included a limited time frame. It is recommended to expand the time period under review, to include other cryptocurrencies within the scope of the study, to examine other influencers in this context, and to investigate the effects of other social media tools. 
Hamurcu, Ç. (2022). Can Elon Mask's Twitter Posts About Cryptocurrencies Influence Cryptocurrency Markets by Creating a Herding Behavior Bias? Fiscaoeconomia, 6(1), 215-228.

Doi: $10.25295 /$ fsecon.1028730.

\section{References}

Aharon, D. Y., Demir, E., Lau, C. K. M., \& Zaremba, A. (2020). Twitter-Based Uncertainty and Cryptocurrency Returns. http://dx.doi.org/10.2139/ssrn.3735435

Ante, L. (2021). How Elon Musk's Twitter Activity Moves Cryptocurrency Markets. Available at SSRN: http://dx.doi.org/10.2139/ssrn.3778844

Choi, H. (2021). Investor Attention and Bitcoin Liquidity: Evidence from Bitcoin Tweets.

Finance Research Letters, 39, 101555. https://doi.org/10.1016/i.frl.2020.101555

Forbes (2021). Forbes World's Billionaires List: The Richest in 2021. https://www.forbes.com/billionaires/ (accessed 05.11.2021 and 07.06.2021)

Kahneman, D. \& Tversky, A. (1979). Prospect Theory: An Analysis of Decision Under Risk. Econometrica, 47, 263-91.

Kraaijeveld, O., \& De Smedt, J. (2020). The Predictive Power of Public Twitter Sentiment for Forecasting Cryptocurrency Prices. Journal of International Financial Markets, Institutions, and Money, 65, 101188. https://doi.org/10.1016/j.intfin.2020.101188

Musk, E. (2021). https://twitter.com/elonmusk. (accessed 05.06.2021)

Naeem, M. A., Mbarki, I., \& Shahzad, S. J. H. (2021). Predictive Role of Online Investor Sentiment for Cryptocurrency Market: Evidence from Happiness and Fears. International Review of Economics \& Finance, 73, 496-514. https://doi.org/10.1016/i.iref.2021.01.008

Nelson, D. B. (1991). Conditional Heteroskedasticity in Asset Returns: A New Approach. Econometrica, 59(2), 347-370.

Öztürk, S. S., \& Bilgiç, M. E. (2021). Twitter \& Bitcoin: Are the Most Influential Accounts Really Influential?. Applied Economics Letters, 1-4. https://doi.org/10.1080/13504851.2021.1904104

SEC (U.S. Securities and Exchange Commission). (2018). Elon Musk Settles SEC Fraud Charges; Tesla Charged With and Resolves Securities Law Charge. https://www.sec.gov/news/press-release/2018-226 (accessed 05.11.2021).

Shen, D., Urquhart, A., \& Wang, P. (2019). Does Twitter Predict Bitcoin?. Economics Letters, 174, 118-122. https://doi.org/10.1016/i.econlet.2018.11.007

Tan, L., Chiang, T. C., Mason, J. R., \& Nelling, E. (2008). Herding Behavior in Chinese Stock Markets: An Examination of A and B Shares. Pacific-Basin Finance Journal, 16(1-2), 6177. https://doi.org/10.1016/j.pacfin.2007.04.004

Tversky, A., \& Kahneman, D. (1974). Judgement Under Uncertainty: Heuristics and Biases. Science, 185(4157), 1124-1131.

Zhang, J. (2020). Do Cryptocurrency Markets React to Issuer Sentiments? Evidence from Twitter. Evidence from Twitter. Available at SSRN: http://dx.doi.org/10.2139/ssrn.3675196 


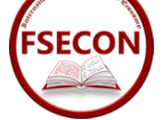

Hamurcu, Ç. (2022). Can Elon Mask's Twitter Posts About Cryptocurrencies Influence Cryptocurrency Markets by Creating a Herding Behavior Bias? Fiscaoeconomia, 6(1), 215-228.

Doi: $10.25295 /$ fsecon.1028730.

Ethics Statement: The authors declare that ethical rules are followed in all preparation processes of this study. In case of detection of a contrary situation, Fiscaoeconomia has no responsibility and all responsibility belongs to the authors of the study. 